\title{
Aggression of patients towards the employees of the National Emergency Medical System
}

\begin{abstract}
Introduction. The organizational structure of the National Emergency Medical system ensures the health of citizens. Unfortunately, patients present dangerous behaviors, thereby damaging the safety of workers during medical emergencies. Aggression and violence, in spite of the widespread perception of it as a negative phenomenon undermining the individual's health, is an indispensable part of everyday life and work environment.

Aim. The purpose of this study was to determine the incidence of acts of aggression that led to violence, and the types of occurrence of this phenomenon, which influenced the staff of the National Emergency Medical system.

Material and methods. The study was conducted in 2015/2016 among the employees of the National Emergency Medical system in Lublin, Puławy and Zamość; the research tool was a questionnaire survey.

Results. On the basis of the conducted research, it can be concluded that the employees of the National Emergency Medical system are, to a large extent, exposed to acts of aggression on the part of patients. Almost all the employees of the Accident \& Emergency Units (98.2\%) and almost all the employees of the Medical Rescue Teams (98.3\%) encountered aggression from the patients.

Conclusion. There observed a phenomenon of aggression as well as verbal and physical violence on the part of patients towards health care workers. Alcohol and drugs increased both verbal and physical aggression among patients.

Employees of the National Emergency Medical system have indicated aggression as an intrinsic element in the work environment.
\end{abstract}

Keywords: aggression, verbal aggression, physical aggression, safety, medical rescue.

DOI: $10.1515 /$ pjph-2017-0023

\section{INTRODUCTION}

The National Emergency Medical system is an integral part of the national security system. Employees of this system ensure the health of citizens. Often, however, they themselves become victims of patients to whom they provide the necessary assistance in saving health and living in crisis situations. Due to various factors that can be dangerous in the work environment, in particular the human factor is at risk. Severe illness is a problem for the patient and the functioning of the health care system in Poland is assessed as insufficient. As a result, system staff, whether a physician, lifeguard or nurse, are blamed for this condition. Individuals, who are on the spot at the time of the most stressful health threat, are dealing with aggressive patients. Workers are attacked by patients who provide assistance. Aggression is an act, violence is the result of aggression. Certain jobs predispose individuals to frequent contact with aggression, where representatives of these professions more often encounter aggression from other individuals. These occupations include medical professions.

The phenomenon of aggression from patients for various reasons is growing, thus causing serious problems. Violence and aggression are the phenomena that have been aggravated in recent years in relation to people who work in the Accident \& Emergency (A\&E) Units and Rescue Medicine Teams. There are often acts of aggression and violence in A\&E. A condition that threatens the health or life of A\&E patients increases anxiety and fear, causes nervousness and increases the level of stress. Stress causes a variety of behaviors, including adversarial or pretentious behavior. Patients are often under the influence of alcohol or other intoxicants [1-5].

The staff of the National Emergency Medical system is exposed not only to physical, chemical or biological factors, but also to human factors such as stress or aggression from patients. The public service workers, who are exposed to danger and aggression, are protected by the status of a public official. Employees of the system enjoy the protection guaranteed to a public official [6]. The rescuer will obtain the status of a public official such are the legislator's plans. Under the new regulations, this status will apply to: people providing health services in a hospital emergency department, medical dispatchers and voivodship coordinators of emergency medical services [7]. 


\section{AIM}

The purpose of the study was to evaluate the safety, scale and identification of aggression of patients towards medical personnel.

\section{MATERIAL AND METHODS}

The research was carried out using a survey tool in the form of a questionnaire. The questionnaire contained anonymous questions (20) concerning the phenomenon of aggression and its causes, and was carried out among the employees of the National Emergency Medical system. Respondents were asked about the biggest source of aggression. The questionnaire also included metric questions: gender, age, education, occupation, length of service and marital status.

The research was carried out in the period 2015-2016 among the employees of the National Emergency Medical system. On the premises of the hospital rescue services in Lublin, Puławy and Zamość as well as in medical rescue teams in these cities. The respondents were randomly selected from all Emergency Medical Services staff. A total of 302 respondents were surveyed, and after verification, the research group had 217 questionnaires that were subjected to statistical analysis. Characteristics of the Medical Rescue Teams was $87.9 \%$ of men and $12.1 \%$ of women. In the Hospital Accident \& Emergency (A\&E) Units $46.2 \%$ of the employees were male and $53.2 \%$ were female. Of the respondents working in the A\&E, almost half (44.5\%) were between 40 and 55 years old. As many as $28.2 \%$ were from 31 to 40 years old. Fewer individuals were under $30(18.2 \%)$ and over 55 (9.1\%). Among the respondents working in the Medical Rescue Teams, almost half $(45.2 \%)$ were from 31 to 40 years old, and only $27 \%$ from 40 to 55 years. Nearly as numerous were the individuals up to 30 years of age $(26.1 \%)$, and definitely the least numerous group of individuals was over 55 years old.

\section{RESULTS AND DISCUSSION}

Based on the research conducted, it can be concluded that the employees of the National Emergency Medical system are largely exposed to acts of aggression from patients to whom emergency medical care and life support are provided. The safety of workers is at stake. Nearly all A\&E workers (98.2\%) and almost all the employees of the Medical Rescue Teams (98.3\%) encountered aggression from patients.

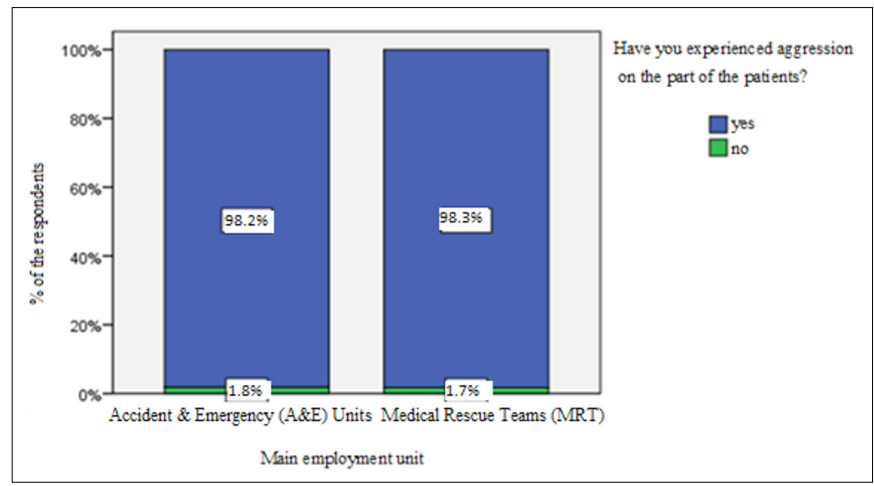

FIGURE 1. Differences in ferritin serum level conditioned by stages of Community Periodontal Index of Treatment Needs (CPITN).
TABLE 1. The reasons for verbal and physical aggression.

\begin{tabular}{lcccc}
\hline \multicolumn{1}{c}{ Reasons } & \multicolumn{2}{c}{$\begin{array}{c}\text { Verbal } \\
\text { aggression }\end{array}$} & \multicolumn{2}{c}{$\begin{array}{c}\text { Physical } \\
\text { aggression }\end{array}$} \\
\cline { 2 - 6 } & $\mathbf{N}$ & $\%$ & $\mathbf{N}$ & $\%$ \\
\hline $\begin{array}{l}\text { The patient was under the influence } \\
\text { of alcohol }\end{array}$ & 207 & $91.2 \%$ & 99 & $88.7 \%$ \\
\hline $\begin{array}{l}\text { The patient was under the influence } \\
\text { of drugs }\end{array}$ & 154 & $67.8 \%$ & 43 & $63.0 \%$ \\
\hline $\begin{array}{l}\text { The patient was dissatisfied } \\
\text { with medical service }\end{array}$ & 110 & $48.5 \%$ & 4 & $32.6 \%$ \\
\hline $\begin{array}{l}\text { Too long time of waiting for the medical } \\
\text { service }\end{array}$ & 149 & $65.6 \%$ & 3 & $41.0 \%$ \\
\hline \begin{tabular}{l} 
Poor state of health \\
\hline
\end{tabular} & 53 & $23.3 \%$ & 1 & $18.1 \%$ \\
\hline
\end{tabular}

Interesting information is provided by the analysis of the responses to the question about the reasons for aggression. The cause of both verbal $(91.2 \%)$ and physical $(88.7 \%)$ aggression, according to the survey, is mostly alcohol. Interestingly, in the opinion of respondents, dissatisfaction with medical care and too much time of waiting for medical procedures result in much more verbal aggression than physical one.

TABLE 2. Forms of verbal aggression and the place of employment.

\begin{tabular}{|c|c|c|c|c|c|c|}
\hline \multirow{3}{*}{$\begin{array}{l}\text { What form of verbal } \\
\text { aggression have you } \\
\text { experienced? }\end{array}$} & \multicolumn{4}{|c|}{ Main place of employment } & \multirow{2}{*}{\multicolumn{2}{|c|}{ Chi-2 Test }} \\
\hline & \multicolumn{2}{|c|}{$\begin{array}{l}\text { Accident \& } \\
\text { Emergency } \\
\text { (A\&E) Unit }\end{array}$} & \multicolumn{2}{|c|}{$\begin{array}{l}\overline{\text { Medical Rescue }} \\
\text { Team (MRT) }\end{array}$} & & \\
\hline & $\mathbf{N}$ & $\%$ & $\mathbf{N}$ & $\%$ & Chi-2 & $\mathbf{p}$ \\
\hline shouting & 97 & $87.4 \%$ & 102 & $87.9 \%$ & 0.016 & 0.901 \\
\hline insults & 94 & $84.7 \%$ & 94 & $81.0 \%$ & 0.531 & 0.466 \\
\hline vituperation & 85 & $76.6 \%$ & 87 & $75.0 \%$ & 0.077 & 0.782 \\
\hline $\begin{array}{l}\text { encouraging } \\
\text { aggression }\end{array}$ & 62 & $55.9 \%$ & 74 & $63.8 \%$ & 1.488 & 0.223 \\
\hline ridiculing & 32 & $28.8 \%$ & 52 & $44.8 \%$ & 6.228 & $0.013^{*}$ \\
\hline
\end{tabular}

$\%$ answers do not sum up to 100 as the respondents may have pointed to more than one answer

Analysis of the variable "place of work" indicates that A\&E workers most often experienced verbal aggression in the form of screams $(87.4 \%)$ and insults $(84.7 \%)$. Slightly less experienced vituperation $(76.6 \%)$, and more than half - encouraging aggression (55.9\%). Similarly, MRT employees most often experienced verbal aggression in the form of screams $(87.9 \%)$, insults $(81 \%)$ and vituperation (75\%). A little less respondents indicated encouraging aggression (63.8\%), and almost half experienced ridiculing $(44.8 \%)$. As it turned out, there is a statistically significant relationship between the workplace and the experience of ridiculing. Patients' ridiculing was experienced by a much greater number of MRT workers (44.8\%) than the A\&E workers (28.8\%).

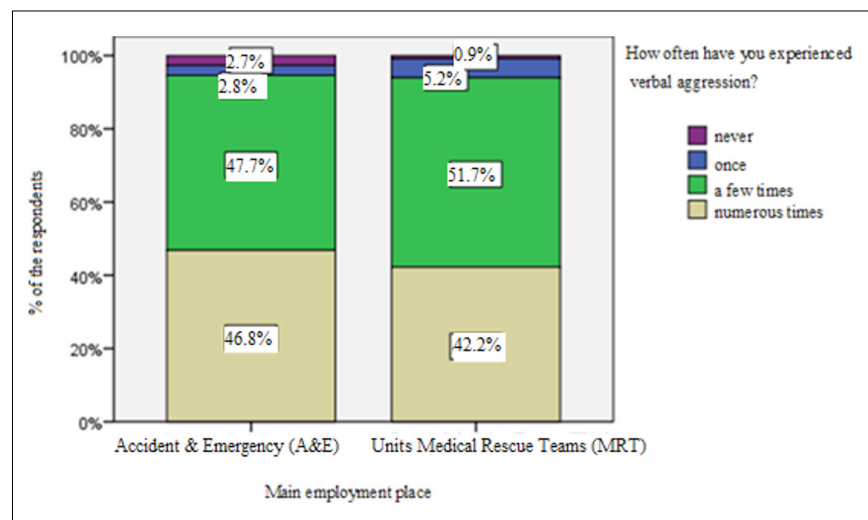

FIGURE 2. The intensification of verbal aggression and the place of employment. 
According to the data presented, almost all A\&E workers experienced repeated aggression $(46.8 \%)$ or experienced it at least several times (47.7\%). Similarly, almost all the employees of the MRT experienced multiple verbal abuse (42.2\%) or experienced it at least several times $(51.7 \%)$.

TABLE 3. Forms of physical aggression and the place of employment.

\begin{tabular}{|c|c|c|c|c|c|c|}
\hline \multirow{3}{*}{$\begin{array}{c}\text { What form of } \\
\text { physical aggression } \\
\text { have you } \\
\text { experienced? }\end{array}$} & \multicolumn{4}{|c|}{ Main place of employment } & \multirow{2}{*}{\multicolumn{2}{|c|}{ Chi-2 Test }} \\
\hline & \multicolumn{2}{|c|}{$\begin{array}{l}\text { Accident \& } \\
\text { Emergency } \\
\text { (A\&E) Unit }\end{array}$} & \multicolumn{2}{|c|}{$\begin{array}{c}\text { Medical Rescue } \\
\text { Team }\end{array}$} & & \\
\hline & $\mathbf{N}$ & $\%$ & $\mathbf{N}$ & $\%$ & Chi-2 & $\mathbf{p}$ \\
\hline spitting & 70 & $63.1 \%$ & 54 & $46.6 \%$ & 6.239 & $0.012 *$ \\
\hline kicking & 65 & $58.6 \%$ & 57 & $49.1 \%$ & 2.025 & 0.155 \\
\hline prodding & 40 & $36.0 \%$ & 68 & $58.6 \%$ & 11.600 & $0.001 * *$ \\
\hline destroying things & 46 & $41.4 \%$ & 59 & $50.9 \%$ & 2.025 & 0.155 \\
\hline pushing & 34 & $30.6 \%$ & 68 & $58.6 \%$ & 17.960 & $0.000 * *$ \\
\hline
\end{tabular}

$\%$ answers do not sum up to 100 as the respondents may have pointed to more than one answer

Interestingly, A\&E workers most often experienced physical aggression in the form of spitting (63.1\%) and kicking $(58.6 \%)$. A little less respondents pointed out: destruction of things $(41.4 \%)$, prodding (36\%) and pushing (30.6\%). In turn, MRT employees most often experienced physical aggression in the form of prodding (58.6\%), slightly more than half indicated destruction of things $(50.9 \%)$, and almost half kicking (49.1\%) and spitting (46.6\%).

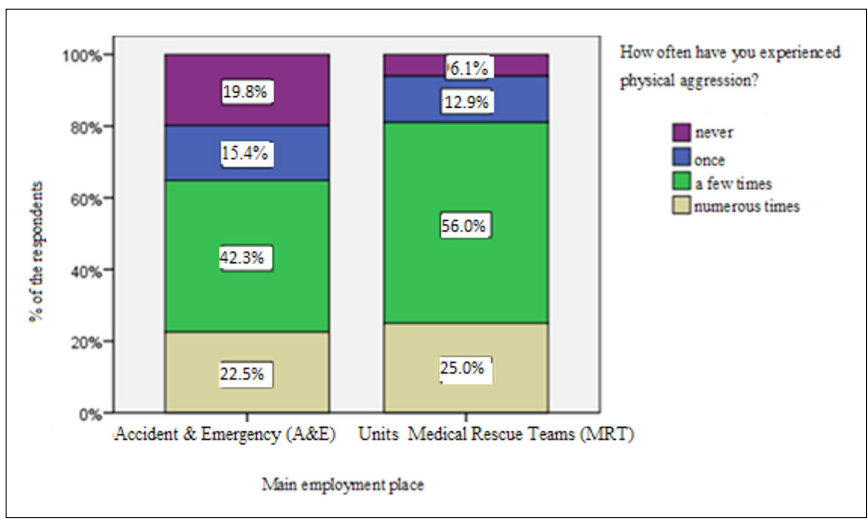

FIGURE 3. Forms of physical aggression and the place of employment.

According to the data presented, both A\&E workers (42.3\%) and MRT employees (56\%) are the ones who experienced physical aggression several times. Approximate percentage of subjects in both groups experienced it repeatedly $(22.5 \%$ in A\&E and $25 \%$ in MRT) or once (15.4\% in A\&E and $12.9 \%$ in MRT). However, there has never been physical aggression in $19.8 \%$ of A\&E workers and in $6.1 \%$ of MRT workers. The Mann-Whitney U test proved a statistically significant difference between the groups in terms of the frequency of physical aggression $(Z=-2.212, p=0.027)$. It is more often experienced by MRT employees than A\&E employees.

The problem of aggression in the workplace was noticed by Wolters Kluwer Polska, which organized a debate on 18.02.2010, which was aimed at initiating a discussion on the growing phenomenon of aggression and violence towards medical personnel. Questions about the source of aggressive behavior towards medical staff, following the discussion, came as a response that one of the reasons was improperly adapted housing conditions in individual hospitalsand too little time due to insufficient medical staff. In the survey, there were also responses concerning the occurrence of acts of verbal and physical violence. The reason for verbal aggression was: dissatisfaction with medical care in the case of $51 \%$ and too much time of waiting for medical procedures, nearly $35 \%$ of respondents gave such answers. In the case of physical aggression, $48 \%$ of respondents pointed to dissatisfaction with medical care and $34 \%$ pointed to too much waiting time for medical procedures. The study clearly shows the increasing problem of patients' attacks against medical staff. The debate was mainly about doctors and nurses, highlighted by the fact that a large proportion of medical rescues are also encountered with violence and aggression [8].

Discussing the results of the research, it can be stated that almost all the employees of the National Emergency Medical system encountered the phenomenon of aggression in the workplace. It was found that A\&E workers were more likely to experience aggression in verbal form and MRT employees were more likely to be victims of physical aggression. In addition to the 2011 data presented, there is also a growing concern about the increase in the level of acts of aggression and violence towards medical personnel. The medical community has noticed the intensification of attacks and the problem of protection at work. System employees are not public officials and only benefit from the status of special protection provided by the Public Officials Act during medical rescue operations $[9,10]$. Changing the structure of the medical emergency system's functioning to nationalize the system will allow better protection of health care workers. A better protected employee feels safer at work. [11]. Patients who are aggressive will not always be under the influence of alcohol or other drugs, but they are also impatient, nervous, because medical procedures are taking too long [12]. The occupational safety and health management system allows the workplace to be prepared more accurately. Appropriate regulations and standards help to avoid dangerous situations in the work environment [13].

\section{CONCLUSIONS}

1. Most of the employees of the National Emergency Medical System, regardless of their workplace, experienced aggression from patients, both verbal and physical one.

2. Disappointment with medical care and excessive waiting time for medical procedures result in more verbal aggression than physical one.

3. All staff of the Hospital Accidents \& Emergency units (A\&E) and all staff of the Medical Rescue Teams (MRT) experienced the phenomenon of verbal aggression from patients.

4. Employees of the Medical Rescue Teams were more likely to experience physical aggression than those of the Hospital A\&E.

5. Alcohol and drugs increase the aggressive behavior of patients as for both verbal and physical aggression.

6. Patients' ridiculing has been experienced by a lot more MRT employees than A\&E employees.

7. A\&E employees most often experienced physical aggression in the form of spitting, digging and destruction of things

8. Employees of MRT most often experienced physical aggression in the form of poking and pushing. 


\section{REFERENCES}

1. Karkowska D. Prawa pacjenta. Warszawa; 2009. p. 216-30.

2. Konstytucja Rzeczypospolitej Polskiej. Komentarz. T. I-V. L. Garlicki (ed). Warszawa; 1999, 2001, 2003, 2005, 2007.

3. Nogalski A, Mikuła-Mazurkiewicz A, Mojsym S. Aggression and violence at Emergency Department and Ambulance Service. In: E. Dybińska (ed). Lifestyle, education and wellness. Lublin: NeuroCentrum; 2012. p. 197 210.

4. Poździoch S. Komentarz: Ustawa o Państwowym Ratownictwie Medycznym. Warszawa: Wydawnictwo Wolters Kluwer S.A; 2013.

5. Rozporządzenia Ministra Zdrowia z dnia 6 czerwca 2013 r. w sprawie bezpieczeństwa i higieny; Dz. U. 2013 poz. 696.

6. Ustawa z dnia 6 czerwca 1997 r. Kodeks karny Dz. U. 2016 poz. 1137.

7. Projekt-ustawy-o-zmianie-ustawy-o-Panstwowym-Ratownictwie-Medycznym-oraz-niektor.html. [https://bip.kprm.gov.pl/kpr/form/r127427395].

8. Wolters Kluwer Polska. Agresja w ochronie zdrowia. [http://www.abc. com.pl/nowosci-branzowe/3374/7]. (18.02.2010)

9. Marek A. Kodeks karny. Komentarz. Lex a Wolters Kluwer business, cop. 2007. Warszawa; 2007.

10. Projekt z dnia 14.10.2016 [http://legislacja.rcl.gov.pl/docs//2/12290956/1 2384436/12384437/dokument249974.pdf] (15.07.2017)

11. Ustawa z dnia 5 grudnia 1996 r. o zawodach lekarza i lekarza dentysty. Dz. U. $2008 \mathrm{Nr} 136$ poz. 857

12. Bryła R. Bezpieczeństwo i higiena pracy. Katowice: Wyd. ELAMED; 2011.

13. Karczewski JE, Karczewska KW. Zarządzanie bezpieczeństwem pracy. Gdańsk: Wydawnictwo Ośrodek Doradztwa i Doskonalenia Kadr Sp. z o.o.; 2012.
Corresponding author

dr Sylwia Mojsym-Korybska

Chair and Department of Public Health Medical University of Lublin 1 Chodźki St., 20-093 Lublin

E-mail: smojsym@interia.eu

tel. 814486380 